\title{
肺・縦隔疾患に対する縦隔鏡検查法(Mediastinoscopy) の実際とその検査成績
}

\author{
大阪市立大学医学部耳鼻咽堠科学教宝 (主任：山本 鳌教授)

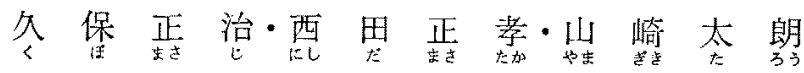

\section{要旨}

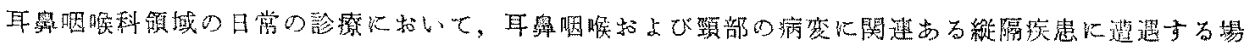
合は，それ程狶ではない。

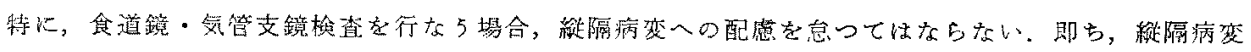
の一部が，食道鏡特に気管支鏡の内視鏡所見を道して把握される埸合がある。

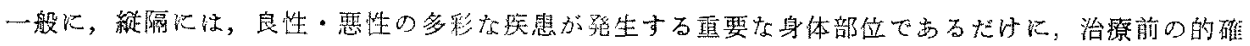

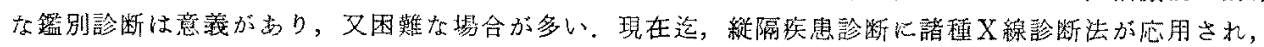
有効な成果が得られているが, 症例飞よつては限界すある。

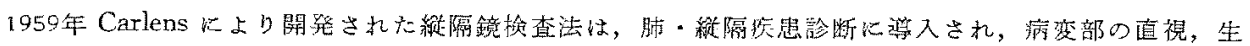

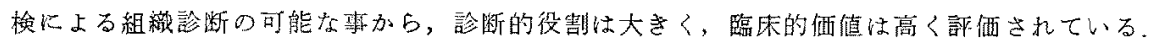

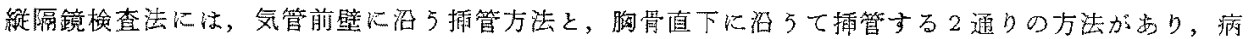
等存在部位に上り使いわける必要がある。

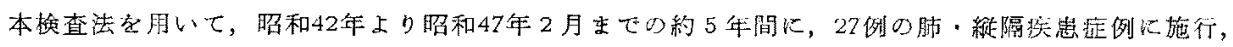

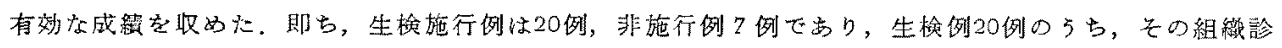

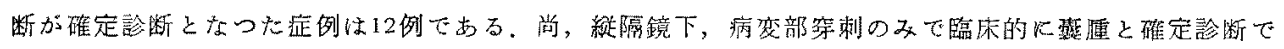
きた 1 例があり，計了例が㭘査前のレ線像で認められた絽隔異常陰影の本体を解明することができた。

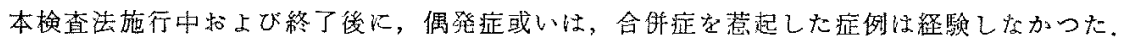

\section{1) 緒言}

耳鼻咽䞍科は，日常，気管・食道の内視鏡診断法を駆 使する診療科であることから，内視鏡梌查時，隣接の縱 隔招上び肺の諸種疾患に遭遇する場合も少くない，即 万，縦隔に発生す万各種疾患は，その進展籁国に上つて は，気管・食道に影響を㧍よぼし，内視鏡検査また注 部X線写真により異常所見として認められることにな る。このことは，綎隔疾患と気管ならびに食道注密接な 関倸のあることを示小ものである。この他，全身的系統 的疾患の部分症状として耳, 舅, 咽喉や頸部領域にも現

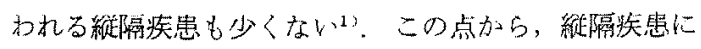
遭遇した場合，その診断には穦極的な配䉥分吧喉科医に む要求される。

従来から，縦隔疾㭧診断には，諸種X線検查法が用い

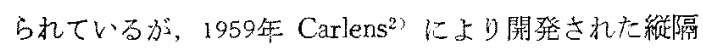
鏡検查法法，X線検査法では追求できない縦隔疾患に詨 しても, 組織学的に診断在確定できる可能性在有し，そ
の診断に大きな意義をもたらすものである。

我々も，昭和42年頭初上り 47 年 2 月迄の約 5 年間に

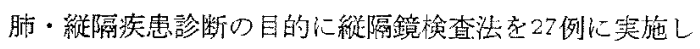
たので，綎隔鏡検查法の寒際と，その成績について紹介 乙御批判老仰ぎたい.

\section{2) 検查症例}

維隔疾患症例は，最初に内科党受診するものが多く， 内科加占診断女るい治療を目的に，関保診療科入紹介 されるのが普通であり，従つて直接に耳鼠咽喉科を受䲞 寸るのは稀である，即ち，27例の当科入の紹介科をみる と，13例が内科，8例が外科，5例が放射線科上引，夫 々気管支鏡方よび維隔鏡検查による診断決定の目的で紹 介されている。

唯, 嗄声が主訴の左反回神経麻㾞の一症例では, 直接 当科を受㟝しているが，本症例住その淩の精査により大 動脈畦であることが判明した特殊な症例であつた（図 1). 
图 1

紹介科の内訳（全例27例）

\begin{tabular}{ll} 
内 科 & 13 例 \\
外 科 & 8 例 \\
放射線科 & 5 例 \\
\hdashline 直挼受喰 & 1 例
\end{tabular}

3）性別・年令

総数27例の5ち，21例は男性で，残り6例が女性で， “ 圧倒的飞男性飞多い，綎隔疾患の多㥞性から年命の分布 山多岐であり，10才代が1例，20才代が4例，30才代吕 6例，40才代方 2 例，50才代が 8 例，60才代が 5 例，70 才代阮1例となつている. 50 才以上注半数以上で 14 例を 占めているが，このらち10例生でが瑟性腫壕であり，13

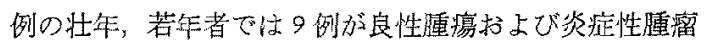
であるサルコイドージスであることは，維隔疾患の特徴 を表放している（図2）。

\section{图 2}

性 別

男性性
21 例

\section{年令別}

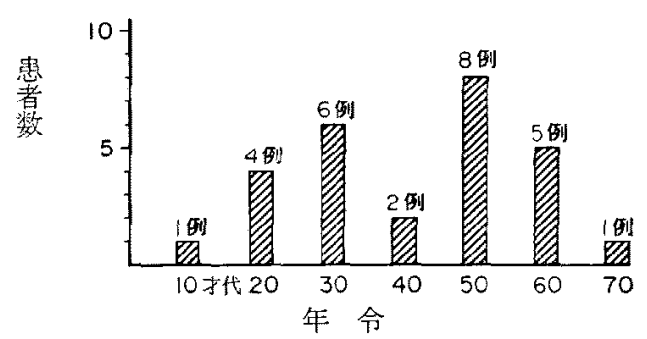

\section{4) 受診時症状}

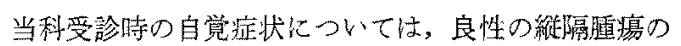
場合，自覚症状を欠人症例が多い，即ち，27例中，自覚

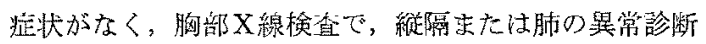
を指摘されて始めて発病を知った症例は 7 例女。。この 5ち, sarcoidosis 3 例, 霆腫性腫额 1 例, 胸腺腫 1 例

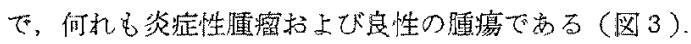

自觉症状を有する症例の主訴の内訳は, 前胸部痛老培

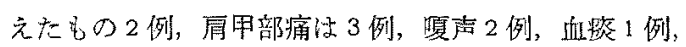

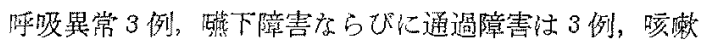
は 4 例㐫り, その他, 原発菓検卖の目的で, 縱隔の精查 を依頼され施行した症例は 2 例である。何らかの自覚症 状を訴えた症例18例中，12例末でが悪性腫瘍であること も診断上参考になる(図 4 ).
图 3

当科受診時自鸴怔状

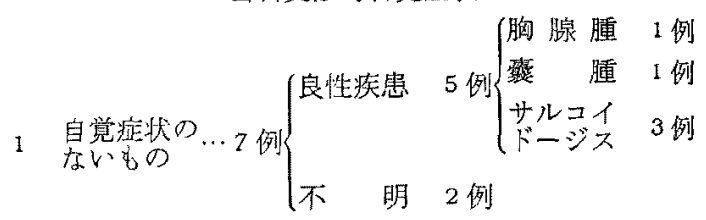

2 自賞症状の $\cdots 18$ 例 $\begin{cases}\text { 雭性疾惠 } & 12 \text { 例 } \\ \text { 良性疾患 } 6 \text { 例 }\end{cases}$

3 原発媳精植…2 例

\section{图 4}

自觉症灯の内容と良性・覀性疾患との関連

\begin{tabular}{|c|c|c|}
\hline & & 良性 \\
\hline 嗽 & 4 例 & 1 \\
\hline 嚾下及び通過障害 & $3 \prime \prime$ & 2 \\
\hline 呼吸異常 & $3 \prime \prime$ & 2 \\
\hline 肩甲部痛 & $3 \prime \prime$ & 0 \\
\hline 前胸部膈 & $2 \prime \prime$ & 0 \\
\hline 嗄声 & $2 \prime \prime$ & 1 \\
\hline 血 & $1 / \prime$ & 0 \\
\hline
\end{tabular}

\section{5) 縦隔疾患診断法}

レ線学的猃惭法として, 各種方法が用いられているが 3)4（図 5), 我々の稀隔鏡検㭗施行前に行5X線検查法 の中て，特に有效な方法と思和孔るすは，胸部正面䯩

図 5

糹隔愺場診断法

1) V線学的検查法

1 胸部单緃撮影 (正側西) 6 血管造影法

2 胸部断濖摄影 (正側面) 7 大動脈造影法

3 胸部正面高在撮影 8 淋巴管造影法

4 気管支造影法 9 縌隔造影法

5 领道造影法気檤隔法)

2) 内視鏡的検查法

1 気管支鏡検查

2 食道鏡稂查

3 縦㵝鏡検查

3) 病理学的検查法

1 斜角筋前リンパ組織生検

圧撮影法, 正側面断尿撮影法, 大動脈撮影法扔よび食道

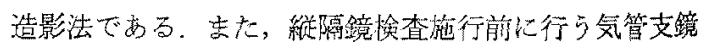

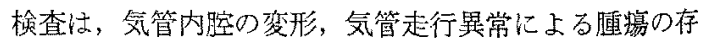
在位置, 大きさを診断する上で，是非試みるぶき検査法 亡荐える.

その他，胸腔内甲状腺蕾の場合は，甲状腺シンヂグラ 


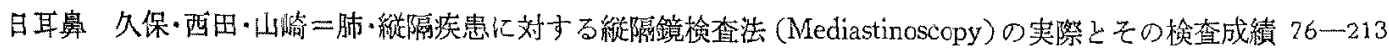

ム汸有効である。

\section{6）縦隔鏡検查法}

(i) 検查器具：15cm と $17 \mathrm{~cm}$ の 2 種類の艮さの管鏡 索使用しているが，これらは管の片側に全長汇亘る裂满 を有するむので，ここ军通して生検鋤子，吸引管拉上び 長さ䄪 $20 \mathrm{~cm}$ の太、穿刺針を夫々の目的に操作する. そ の他, 検查中の綐隔内深部の实斯性出血には電気メス尖 も準備し，必要に応して使用することもできる3(写真 1 ).

(ii) 検査手技：麻醉は程口掅管全身麻醉で，局枕を用 い,従つて体位は项部伸展，後頭部下垂の仰卧位である。

a ) 気管前壁仁沿い雨管する方法.

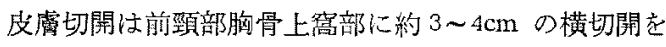

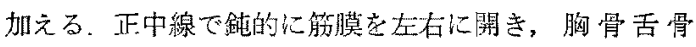
筋, 胸骨甲状筋を左右に圧排し，気管前筋膜に達し，こ の筋䑏に横切開を拖し，気管前壁を露出する．次に，気 管前壁と気管前筇膜の間に作製された腔内に示指を搜入 し，気管前壁に沿い，深部へ向って気管分岐部まで疎な 結合織老㢦離し内腔を抎げる。この操作途中，示指の指 腹で大動脈の搏動を触知する。このようにして十分な㔀 離操作の後に，腔がかなりの広さになれば，管鏡を気管 前壁に沿い，注意深く徐々に分岐部まで捵入していく。 そして症例に応して，左有の主気管支の領域充でる操作 を行う。

挿管操作の過程に扔いて注，気管雨側壁附近の变化を よく䘽察する、即ち、気管营りンパ節の状態を梌索しつつ 操作を進め，病变を認めない場合，更に深部に向、操作 を進めていく、もし，リンパ節の腫大，あるいは腫瘍性 病変を見出した場合，その周囲組織在十分に剝激した後 に，先ず病巣の試験穿刺を行い，血管でないことを確め た後に，生検鈷子を用いて試験切除を行 5 。この場合， 可能な限り病巣部の数個所上り切片を棌取する。試験切 除後の組織からの小出血はボスミンガーゼによる压迫で

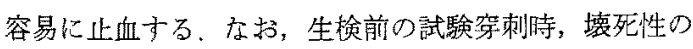
变化走示腫演の場合，吸引した内容物から細胞診䘮行

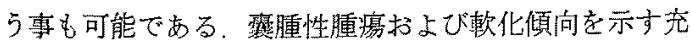
実性腫瘍の試験切除時には，内容液等の窒内流出がおこ り感染の危険がある。このような場合に注速に太、吸引

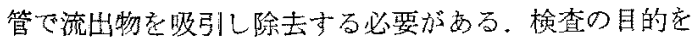
終えたならば，創腔内に抗生物澌を用い，出血部位のな いこ上を十分確めた徭に，一次的に筋層縫合，皮濾縫合 を行い検查意終わる。

b) 胸骨捘面の病巣に対寸る挿管操作.

検查前のレ線写真によつて胸骨後部に近接した胴瘍陵
影を認めた場合，捅管は胸骨後面に沿以行ら。この場 合，患者の体位で前者と異なる点は，䐚骨後面の腫蒜の 位置が左右の何れに偏しているかをレ線写真で確認した 上で，左右何九か心頭部の位㽞を片寄らせた方が操作儿 好都合である。例壳ば，正中線上り右側に腫县が存在す る場合，頭部を右寄りに招き，雨管は頭部の左側より行

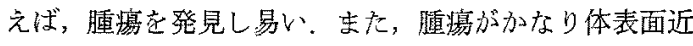
く存在する場合は，下方から上方を見上げる姿等になる 為に，管鏡の先端恃上方に向き，従つて検者の位置はず つと下位になる。

手術は皮虞切開，筋膜剝離屯での操作は，a）の力法 と同様であるが，気管前筋膜を切開することなく，直ち に胸骨柄の上緑を求め，ここに附着す方筋肉在剝離，左 右八圧排の後, 胸骨後面に沿い，示指を插入し，この部

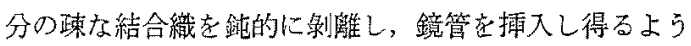
な腔を作る．次いで，鏡管を胸骨後面に沿るせ乍ら，先 端を押し上げるような気持ちで㨂入して行き，病変部を 捜寸，病笨部位発見後の操作はa）と同檬である。

\section{7)生検成結（図6)}

縱隔鏡湌查施行 27 例中, 生㛟施行例は20例, 非施行例 は 7 例である. 非施行例 7 例中 1 例は，試験穿刺のみに

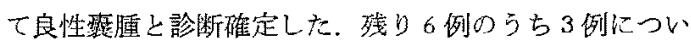
ては，綐隔にレ線等で異常陰影を認めないが，原発県精 查の目的で行つた1例と，他はレ楾像で膄澶性陰影を疑 わしめる所見を示したため確認の目的で本法を施行した が，レ線像に一致した病変部位の存在索確認し得なか力 た 2 例計 3 例の生㭘非適応例亡，残り 3 例は技術上の問 題で，堙瓄が存在したにも拘らず，試切を行なら適確な 病変を発見できずに検査妾終り，何れも先の後に行われ た外科的開胸手術吉上び死後剖検の結果, 肺癌 2 例上 1 例の giant cell sarcoma が碓定診断されたものである。

生梌施行例注20例で，生検結果が確定診断上異なつた 症例安紹介寸ると，症例 9 は本検查前のレ線写真上，綎 隔異常陰影老認めず，原発䁷精查の目的で本法を施行し たのであるが，その際，縱隔内りンパ節の生検を行つた 結果, anthracosis の組織像得た症例で, 本症例の 臨床診断は Hodgkin's disease で岁った。

次は，維隔に異常陰影を認好乍ら，主病変が発見でき

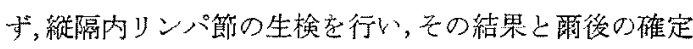
診断と異つた症例である。先ず，気管気管支リンパ節の生 検猃断が anthracosis の 3 例では2例が肺癌, 1 例が大動脈

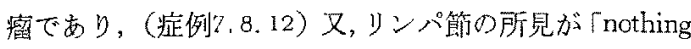
particulary」の2例では1例は, teratoid tumor, 他は ma- 
图 6

維隔鏡榆查下生検組織猃と確定診断との関係

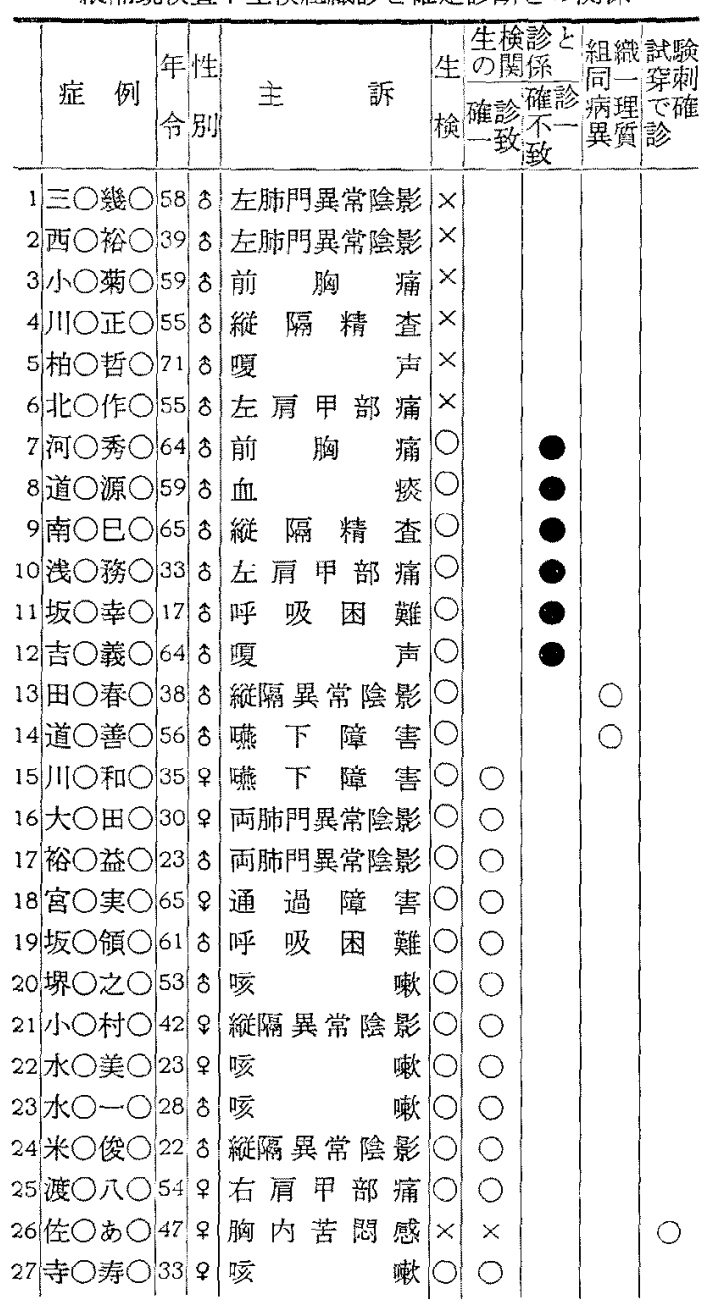

lignant”thymoma であつた。（症例 $11 ， 10$ )

次に検体からの組織診と，爾後の手術時診断或、は死 後剖検所見と一致した症例は20例中12例である。，又，診断 は一致しないが，発生組織が同一臟器のもの仕 2 例であ る.即ち，その1例は生検組織が胸腺様組織であり、開胸手 術時の組織診断が thymoma であつた(症例13). 他の1例 注生揄組織が thymoma で, 外科的摘出手術時の病䉾よ りの組織診断が malignant thymoma であった(症例14).

生検に上る組織像から，診断が確定した12例の涘患の

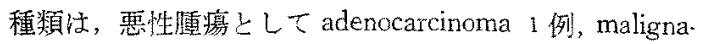
nt neoplasm 4例, 良性霾煌として thymoma 1 例, heterotopic struma 1 例, brorchogenic cyst 1 例, dive-

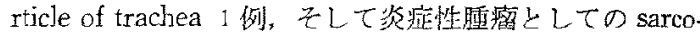
idosis が 3 例計12例である。，その他，病栄の試駼呀刺の

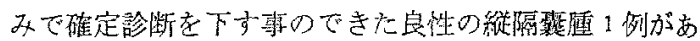
当(腚例26).

組織診に併行して細胞診在行つた症例が2例あり，1例 注 malignant neoplasm の症例で,細胞診でも同様の彭断 が下された(症例23). 他の1例は唯腫性の夏性腫瑒であり， その穿刺内容液を検体として梌索したものでするが悪性 所見注得ら狄なかつた（症例22）。即ち，維隔鏡検查下， 各手技を用いて診断索確定できた症例は13例であった。

\section{8) 症例}

(i) 縦隔鏡検查に上り, レ線写真上肺, 絴隔に罣常陰 影を認め乍ら，䋊隔内に病集を発見できず生検を行い得 なかった不成功例にっけて記盏する。

a) 症例 5 ，柏○哲O，71才，合。

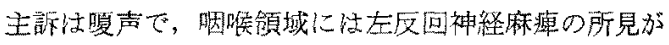
子られ，胸部以線断層掫影で左肺門部の陰影增强があり，

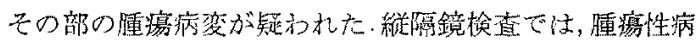
変を確認し得ず，試験切除を行う事度く梌查を終えた。

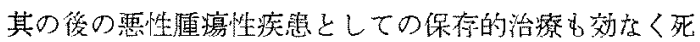

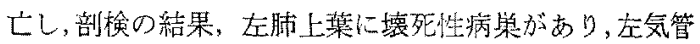

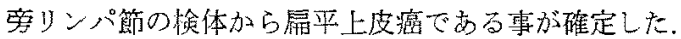

b) 症例 6 , 北○作○，55才， 。.

主訴江左局甲部痛で, 胸部正側面监紽のレ線像で, 気 管左側に接して大きな境界鮮明な異常陰影があり，側面 断尿写真で， $5 \mathrm{~cm}$ の部位で最も明膫な腫瘍㥞陰影を呈し た。縱隔鏡検查施行時, 病巣発見できざ，外科一転科

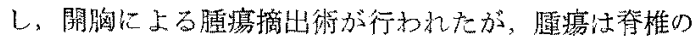
左側後方儿近接し，椎体骨一の部分的浸潤む韶好られ，

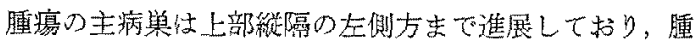

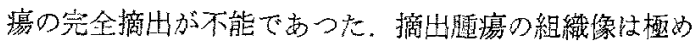
$\tau$ bizarr な giant cell を混じた sarcomatous な增殖方゙ あり giant cell sarcoma と診断された。

(ii) 縱隔にレ線像で異常所見認めたに拘らず，緹隔 鏡検㚗に上つて病变加発見出来ず，一忘気管周囲リンパ 節より試䮖切除を行つた症例で，穵の後の梌索に上り， その組織所見と異なる確定診断が明らがなつた症例で 女る。

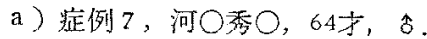

主訴注前胸痛で，胸部レ線検查で，左肺に買常陰影を 認め, 縦隔鏡悇查夌行つた所, 悪性所見を疑わせる病变

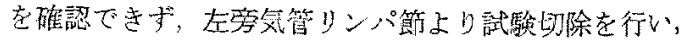
組織学的検索の結果, anthracosis を混えた悪性所見の 


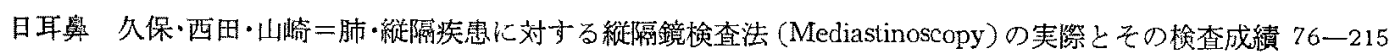

ない正常りンパ節構造を示した症例であつた．

検査後, 外科にて開胸手術の結果, 肺癙である事が判 明した。

b) 症例 10 , 浅○務○，33才，8。

主挀は左局甲部痛で, 胸部正側面レ線で, 左肺門部の

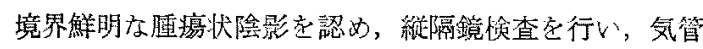
前壁に沿った領域を検索したが，異常所見を発見でき ず，左気管気管支りンパ節より生榆の結果，正常リンパ 節構造を示すのみといら所見学得た。例し，臨床的には 悪性腫癔性疾患としての治療を行つたが，効なく死亡し

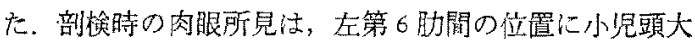
腫瑱が胸骨の直下にあり，左上方即方左肺の上葉にまで 進展して招り，之の病怸部からの病理組織学的検查の結 果, malignant thymoma の診断が明らかとなつた。

c) 症例11，坂○幸○，17才， 8 .

主訴抙吸困難，胸部レ線正面像で左肺門に明らかな 腫疸状陰影が存在し，大動脈撮影によつて，大動脈の走 行は腫瘍性変化とは無関係な位硻で造影されている事を 確認し，その㣪说隔鏡検查を施行したが，左気管気管支 リンパ節からの生検では，正常リンパ節構造を示す以外 著変なく, 従って外科一転科の後, 關胸に上る腫禓摘出 術をらけた，手術所見は，前上縦隔に成人の手學大の㜪 腫性の腫瘍が存在し，摘出瑟腫の病理組織学的検索の結 果, teratoid tumor である杂が確定診断された。

d) 症例 12 ，吉○義○，64才， $\hat{o}$.

主訴は䧗声で, 本唡查施行例中, 直接当科を受㟝した唯 一の症例である。閒接喉頭鏡検查で左反回神経麻瘁と診 断され，胸部レ線撮影によって左肺門上部に異常陰影が あるが，大動脈撮影によつて大動脈㨨江否定された，維 隔鏡検查索施行したが，上線上見られた病変部位を確認 する事が出来ず，気管周团リンパ節加らの試験切除を行 い, その組織学的な検索で注, anthraccsis を示す以外, 病的変化を示さないリンパ節である之診断された。その 後, 再度確認の為に施行した大動脈撮影により大動脈瘤 による䧔影である事が判明した症例である。最初の大動 脈撮影の場合は, 動脈简の病変部まで, 造影剂が到達し てなかったことによるものであつた，尚，本症例は梅齐 血清反忘陰性であった。

(iii) 縱隔鏡検查により，レ線上に認められた異常險影 の病巣が，縦隔鏡検查により確認でき，病柴の一部から 武験切除を行い，その組織所見が，手術又は剖検に上る 組織所見との間に，発生組織洼同一であるが，病理組織 所見を異にした症例を挙げる。 a) 症例 13, 田○春○，38才，各。

縦隔異常陰影を胸部X線検查で発見された自觉症状の

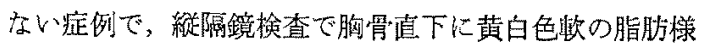
組織に包まれた腫瘍状組織を示し，試切の結果胸腺嵄組 織といら所見のみで，確定㟝断を得られず，外科一謓科 し, 開胸摘出手術をうけた所, 肥厚した被膜を有する䎬 隀性の thymoma と確定した。

b ) 症例 14 , 道O善○，56才，8。

主訴は燕下障害，他觉的に前胸部に上大静脈症候群の 顕著に現われた症例で，就隔鏡検查の結果，胸骨直下に 球状の黄白色軟の婳瘍性変化を示す組織を認的，生㭘を 行つた所, thymoma suspected と組織診断され，外科 にて開胸手術時, 病宩部位とみられる組織からの病理学

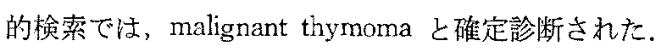

(iv) 絎隔鏡検查により，乙線検査所見と一致した部位 に腫惶性病変を発見でき，その生検診断が，疾患を確定 した症例を示す。

a) 症例 $15, \mu O$ 和 0,35 求, 牛。

主新社鮕下障害.内科から紹介された患者で，全身的 には䇔瘦が顕著で，特に雨眼臉裂の狭小が目立つ顔貌を 呈した。

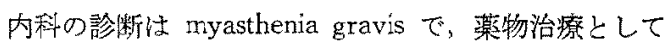
Mytelase の投与をらけていたが，薬効が得られず経過 していた所, 胸部単純および断層撮影に上り胸骨後部に

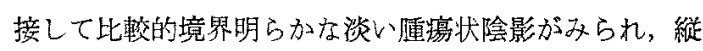
隔鏡検查による精查の目的で当科仪紹介された。

経隔鏡検查は, 胸骨直下の管鏡挿入程路に上り行つた。

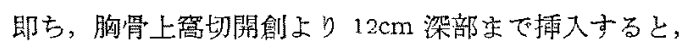
被膜总もつた黄色分葉状心整液腺に類似した腫瘍が存在 し，生検の結果，リンバ球上上皮成分の混在した thymoma の組絨診断妾得た（写真 2). 即ち， myasthenia gravis に合併した thymoma 症例で, 診断確定後外科で

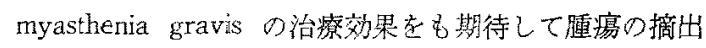
手術が行われた（写真 3 ).

b) 症例16, 大○田○, 30才, 9 .

脑部レ楾検查により，两肺阴の異常除影を指摘され， 内科汃ら沼介された症例で自觉症状を欠く，唯, 病歷と して, 受診の数か月前に右顔面神経麻瘨, 両側視力障害 をきたし，夫々治療をらけた事がある。

縦隔鏡検查により，気管右側に弹性軟，癌着の少い腫

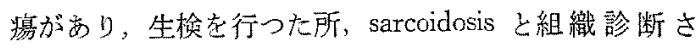
れ，ステロイドホルモンによる治业が行われたが著勃を 示さなかつた。 
c) 症例 17 , 裕○益○, 23才, $\hat{\delta}$.

職場での健康診断で，両肺門部異常陰影を指摘され， 自覚症状を久く、縱隔鏡湌查下，右穷気管リンパ節より 試切を行い， sarcoidosis の確定診断が明らかとなつた症 例で（写真 4)，本例はプレドニン治療で，治療前の両 肺門部の異常險影の消失した著效例である。

d) 症例 $18 ，$ 宮○奏○，65才， $\hat{0}$.

主訴は食道通過障害で, 胸部レ線上縱隔陰影の左右へ の㹡大，左肺門部の突出した腫演性変化がみら机（写真 5 ），先ず気管支鏡検查至行つた所，上門歯上り $25 \mathrm{~cm} の$ 部位に気管左側壁の膨隆があり，内腔の狭害を示した。

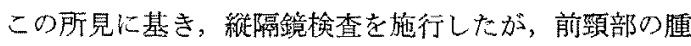
脹が顥著で，気管前壁に達するのに困難を極めた症例で ある、気管前壁に到達する上，縦隔深部までの気管の走 行は，腫瘍に上る圧迫の為，右方へ変位していた。この 気管前壁に近接し, 暗褐色, 易出血性, 充春性の腫韵組 織吕，縱隔梁部まで連続伸展しておうり，組織の一部に試 切赵加へると甲状腺由来の組織に類似し，出血傾向が著 明であった。組織学的検索の結果, heterotopic struma と診断された（写真 6)）との後の甲状腺シンチグラム では, 緶隔内広䇿に陽性所見が認められ(写真 7 ), そ の後第 2 外科で行われた開胸に上る摘出手術を容易にし t(写真 8$)$.

e) 症例19，板○領○，61才，。.

主訴は呼吸困難，上大静脈症候群の著明に現われた症 例で, 胸部レ線像で左肺門から肺上野にかけて腫瘍性変 化並びに無気肺が疑われた。

䋖隔踥検查で左芳気管リンパ節は灰白色，四凸不整

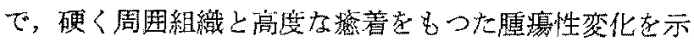
し, 試験切除の結果, malignant neoplasm の組織診断 であつた。

Betatron X楾儿上万放射線治潦を行い，6，800Rを照 射した所, 治療前の胸部異常陰影㴼小改善した。

f) 症例 20 ，罚○之O，53才， 。 .

主訴は咳睎で，胸部レ線で右肺門部から鎖骨の高さま で異常陰影があり，綎隔鏡検査で腫湟性変化を示寸右側

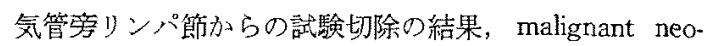
plasm の組織診断乞確定した. Betatron X線 4,000Rの 照射に上り治療前の病的陰影は完全に消失した。

g) 症例 21 ，小○村○，42才，3。

自営症状点欠き, 健康診断での胸部単純し・線写真で, 右肺門部に境界鮮明な異常陰影を指摘され，始めて発病 に気付いた症例である。高圧胸部レ線撮影で気管分岐部
直下，特に右力に球状の陰影が認められた，気管支鏡検 查で Carina から約 $2 \mathrm{~cm}$ 媣部の右主気管支の内側壁の 膨隆・突出の為飞，この部位の内腔の狭窄がみられた

效隔鏡検查で，丁度白いゴムボールが，気管分岐部の

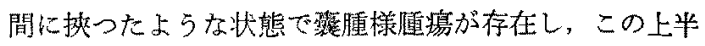
部だけが視野に上らえる事ができ，この一部を第刺する と，壁活弹力性を有し，厚々且一強制で，黄白色，ム天

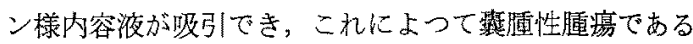

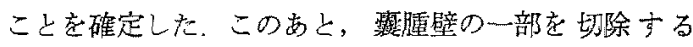
と, 約 $50 \mathrm{ml}$ の貯溜液が維隔内人流出し, 速かに吸引, 排除した。

整腫壁の組織診断は bronchogenic cyst であつた。

h) 症例 22, 水 $\bigcirc$ 美○，23才， 9 .

主訴江咳濑．胸部レ線缘で，右上縦隔の正中部飞近 く，罢常陰影があり(写真9), 側面断層で明らかに病 変の全貌を知ることができた，気管支鏡検查で上門歯よ り $23 \mathrm{~cm}$ の部位に，気管右側壁の内腔への膨隆を認め た.

縦隔鏡検查で，気管壁右側に隣接した暗紫色，菲薄な

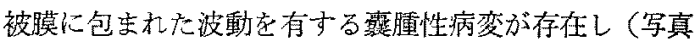

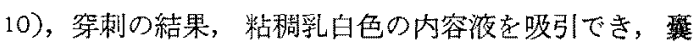
腫壁の一部試験切除により diverticle of trachea の組織 診断を得た (写真 11$)$.

i ) 症例 23 , 水 $\bigcirc-O$, 28才, 战。

主培は咳濑。胸部レ線で上部緃隔に異常陰影があり， 上大静脈症候群の影著な症例でるる。

絽隔鏡検查で，右側の気管旁りンパ節に相当する部位

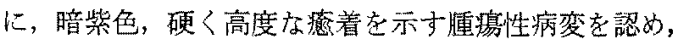
先ず穿刺し，次いで生検を行つた，細胞診，組織診共に malignant neoplasm の診断を得た。

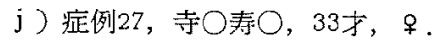

主訴は啨濑。昭和46年春頃から誘因なく峐濑があり， 8 月に他院内科を受糡し, 胸部レ線撮影の結啉, 右肺門部 の結核性病変之診断され, 以後, 結椟専門病院入院の上, 12月末まで SM, PAS, INA に上る治潦を受けたが効果な く，一旦退院の後，当院内科を紹介さ礼受診した，経気管 支鏡ブラッシングによる細胞診をらけるも悪性所見を認 めなレとのことで,繸隔鏡検查の目的で当科を受診した。

縱隔鏡検查により，右気管気管支リンパ節の部位に， 外観上, 小豆大, 青絮色のリンパ節を認め, 試験切除を 行う．表層は正常リンパ節棈造の感触であり，深層は硬 く，薄灰白色の充実性変化を示して扔り，この部から試 駼切除を繰り返し，標本を採取した。 


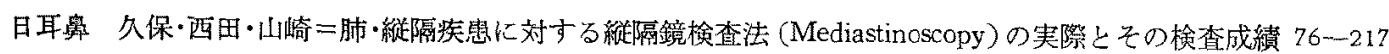

切片の H.E, PAS 染色標本から，小管腔形成ムテン 形成の顕著な腺癌と組織診断された肺癌転移症例である (写真 12).

(v) 縱隔鏡下，病変部の試験穿刺のみによつて，内視 鏡的に祅断を確定した症例を示す。

症例26，佐○め○，47才，果。

主訴法胸内苦閦感. 炤和 45 年頃から階段を昇る際の呼 吸速搏，胸内苦悶感を自営し，46年10月頃加症状增強 し, 胸部絞拒感拉よび左上肢への放散痛も加つた。

近医での胸部レ線検查の結果, 当院内科へ紹介され, 胸部断層正面写真で $12 \mathrm{~cm}$ の部位に境界鮮明な異常陰影

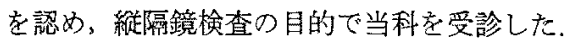

縱隔鏡検查は，胸骨直下のルートを経由して挿管して いくと，胸骨上緑上り数 $\mathrm{cm}$ 深部に，球状，弾性軟の青

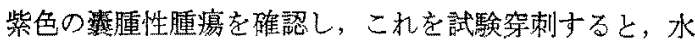
様透明・粘䃬な内容液を採取寸ることができた，内視鏡

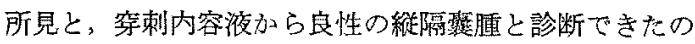
で，敢えて霜腫壁の試験切除を行うことなく，検查を終 了した症例である。

\section{9）総括ならびに考案}

紓隔鏡検查法 (Mediastinoscopy) は 1959 年 Carlens

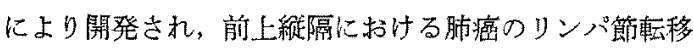
の有無, ならびに肺癌手術の適否の決定の目的で, 以前 より行われている淕験開胸手術あるいは Daniels' operationよりる安全性および確䒠性の点で優れた有益な梌查 方法として肺，紸隔疾患に導入されてきた（図 7 ).

諸外国特にヨーロッパでは，本検查法怯咽喉科医に上 つても気管支鏡操作と同様仙内視鏡検查法の一環とし

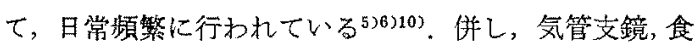
道鏡検查と異なり，前頸部皮切部加らの捙管操作执よび 全身麻酔下施行の特殊検查で㐫る為，検查前の患者ある 、は家族に対する十分な説明，了解吕必要である。縦隔

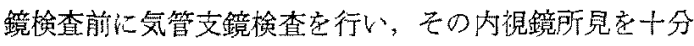
他把握し，縦隔鏡検查に臨むことは，病变部の発見を容 易にし，検查成績の向上に役立つ．本検查法は各種診断 法を行つても，肺・綎隔疾息の本体を解明できない場合 に行ら最後の診断手阯さして用いる可き検查法と考え る.

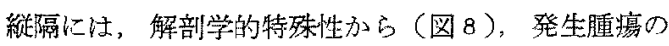
種類も多く, 発生頻度別では, 神経性腫瑔あるいは奇型 腫が最も多く，次いで胸腺嗹が挙げられ，この3種類の

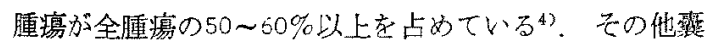

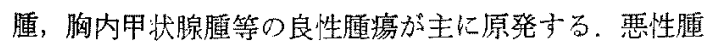

图 7

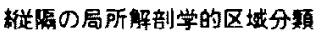

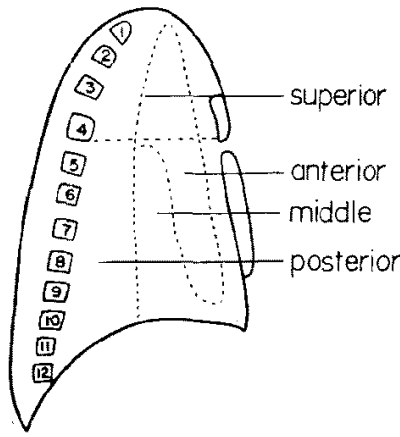

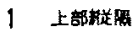

2 下部赫略

i) 前辞结时

ij) 中部咞展

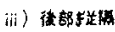

\section{図 8}

綖滆各部にある臓器

1. 上部縰㢳

気管，食道，胸腺，大動脈拉よびその分岐，上大 静脈の上部，無名静脈，胸管，迷走神経，反回神 経, 横隔神経, 交感神経, 時に甲状腺が下降

2. 下部縦隔

(i) 前部緃隔

結合織およびリンパ節

(ii) 中部䋡隔

心贜南よび外膜，上行大動脈，肺動静脈，上大 静脈の下部，気管分岐部，左右主気管支，横隔 神経

(iii) 後部縱隔

下行大動脈，奇静脈，胸管，食道礼上びりンパ 節

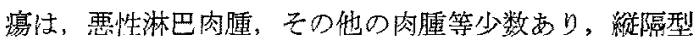
癌は殆んどが続発性である。

腫痬の発生部位として，悪性腫演法不定であるが，良 性腫晹は組織，器官の基盤の上に発生し易い為に，その 部位は腫瘰の種類によつてほぼ一定し，三に前縱隔には

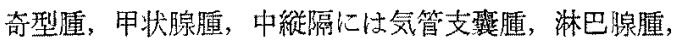
後維隔には神経性腫瘍が発生する，従つて，レ線検查で

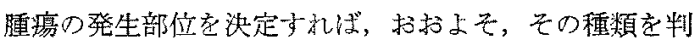
別することは必ずしも困難ではない，即ら，最初に繸隔 疾患の存在を知る手脚りは，多くの場合，X線による胸 部単純撮影である。夫㐫の症例の更に詳細な局在性拉上 び疾患分類㕝追求する為に，正側面断算撒影，気管支造 影, 食道造影法等のレ線学的䛦断法を駆使する。その 他，胸腔内血管性の病変と鑑別する為に，必要な血管造 
影法も行5。即ち，大動脈溜による䋖隔簧常陰影の埸 合，本法が禁忌の立場から，先ずワ氏反态に上る血清学 的補助骖脚法も是非行い，大動脈撮影法も仵行して行与 必要がある。

咽喉科医が日常頛慗に用いる気管支鏡検查では，縱隔

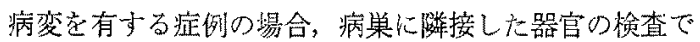
ある為に, 縦隔病変が気管支鏡梌查時, 植接, 間接に变 化在らけている愓合む少くなく，雨後の維隔鏡検查を有 利に導く場合が多い

甲状腺シンチグラムについても，胸内甲状腺腫が稀で ない娭患であることから，それが疑孙れる場台，試みる ことは意義がある。

縱隔鏡検查法比上り最も確実な成果を期待し得る絖隔

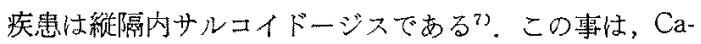
rlens や Pätiäla 导指摘している点であり，著者の施行 症例の中でむサルコイドージス全例に正しく組織診断が 得られている。本疾患の場合, 病変部位加ら生検鉜子に よる試験切除が行い易く, 従つて標本作製後む, 切片採 取時の外力に上る組織の変形挫隇がなく原形をとどめ顕 徽鏡観察が容易で，組織診断を下し易い，一力，覀性腫 韵の場合，殆どの瘇瘤は硬く，生険斜子による組織片の 鉗除法困難なことが多く，その為過分な力が入り組織の 压挫，変形を招き，詳細疗組織分類が不可能な症例が多 かつた，従つて，この上らな場合，病変部位を認好たな らば, 試験切除を行ら前化, 病巣周囲の慦着の高度な結 合織を十分に剢離をした上で，目的に応じた適正な鉜子 を用いて試験切除を行ら事が望ましい，又，病変部所見 によつては，組織診のみならず，穿刺し吸引採取し得た 検体の細胞颜を行う事は, 補助的㟝断として有意義であ る。翟腫性嗹癔の場合，架刺により内容液が証明でき露

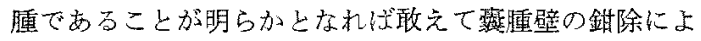

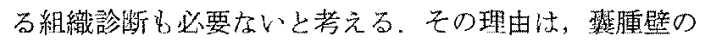
試験切除後生じた小れより，多量の持続的な内容液が縱 隔内一波出寸る為, 視野党奶げるの孙ならず，感染も危

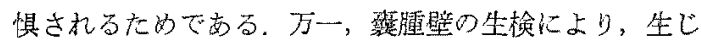
た欠損部加ら内容液が多量に流出し，縦隔内に立満した 場合，直ちに太、吸引管竞用い，内容㴕を排除する必要 がある。

病巣部の試騟切除前の試䍄穿刺は是非行う可き操作 で，血管との鑑別の為に必要である，即ち，生検操作に 際し最む危除な血管損稘を未然仿防ぐ事にもなる。一般

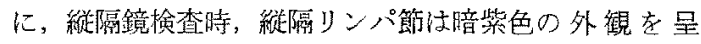
し，静脈と到別儿難い。

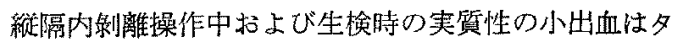
ンポンによる压迫，あるい注ボスミンガーゼの一特的压 迫で簡単に止血する，小血管の離断又は切断による動脈 性の小出血纪遭遇した場合でも，ボスミン綿によって， 整時強い压迫を行う。なお出血の持続する場合には，更 に才キシャル綿球をもつて出血部位に充嚗, 圧迫するこ とにより止血可能である。狭小な検查野における危険な

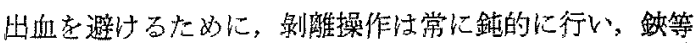
のような鋭利な器具は用いる可きではないと考える，他 の止血法として，実質性り小出血には電気燒灼法を用、 ることもある。また，止血剤を浸した綿球を出血部位に 圧迫する方法む行われる。

綎隔鏡検查中の出血で，A. pulmonalis を損傷して開 胸止血処㯰を行つた報告例がある。

検査による併発症として出血の他に，反回神経麻痺， 気胸，血胸等が挙げられるが，こ机らの偶発症は，本法の 基本手技である気管前壁の正中線に沿らた鈍的剝離, 鏡

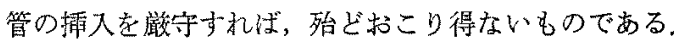

併し，胸腺由来の病変部位の検索の為の，胸骨直下の 本損查は，気管前壁汃ら遠隔の部位の操作の為に，気管 を示標にすることはできない，従つて，できるだけ胸骨 役面にはわ寸如く, 深部に雨入しつつ, 病巣党検索せ放 ばならない。

本険査施行当初は，レ線で認めた病栄を確認出来ない 為，生検を行和ないで検查を終えた症例や，転移を予測 して維隔リンパ節加らのみ, 圾駼切除を行つた不成功例 が多い。この理由は，検查前の諸種X楾写真による病変 の存在部位磼認の不備, 又は, 胸骨直下の異常陰影を示 す症例に対する検查手技が不卜分であつたことが挙げら 机る。

本法成功の要点は，綎隔鏡検疍施行前に，前述の必要 な各種検查を行い, 病変部位を明確に把握し, そして気 管前壁儿沿う可きか，胸骨後面の操作を行う可きかを予 め決定して押く事である。

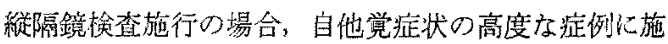
行しなければならない場合むある。即ち，縱隔内腫疼の 広範な進展の為に，周囲臟器，組織への圧迫症状が強く 現われた症例の中で上大静脈症候群の高度な患者は，皮 漕切開部位の頸部の腫脹, 血管怒張により，山血傾向が 强い為に，操作が難行する場合が多い，このような症例 に施行する場合, 完全な止血処置を行いつつ, 慎重に操 作を進めなければならない，

本検査法の禁忌注，大動脈瘤，高血圧症，動脈硬化症 
久保論文付図 (I)

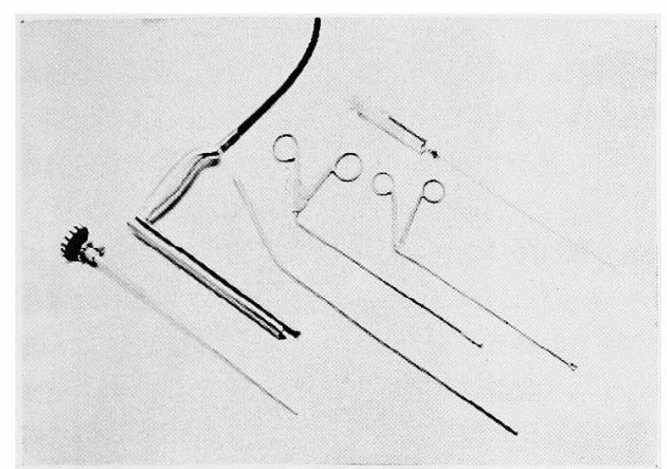

写真 1 縦隔鏡検查器具

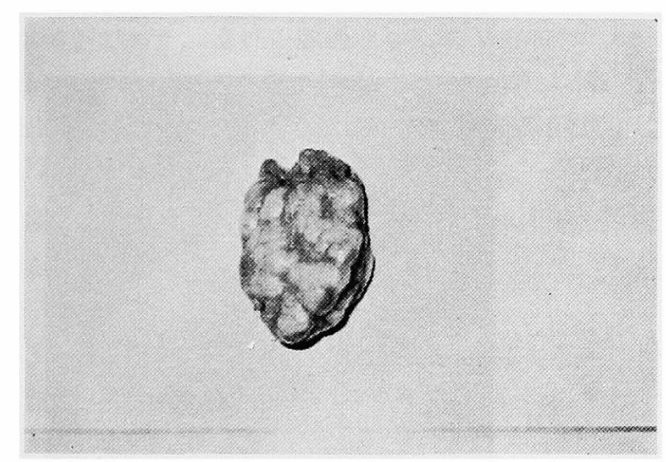

写真 3 摘出胸腺腫

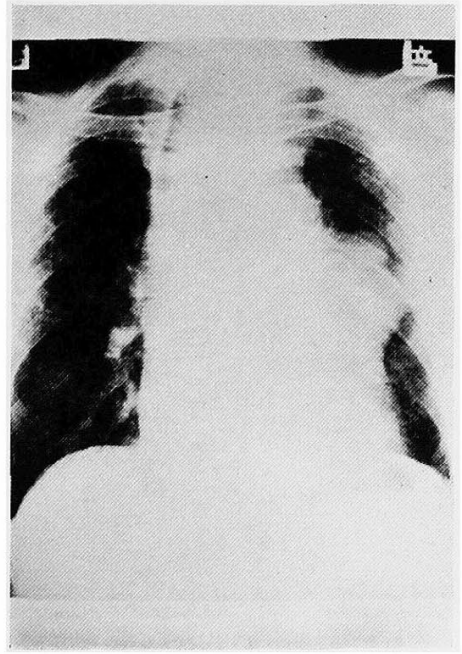

写真 5 胸内甲状腺腫胸部 X線所見

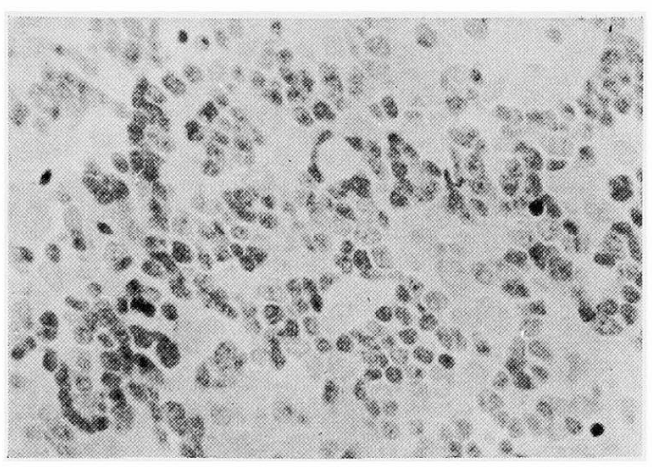

写真 2 胸腺腫組織像

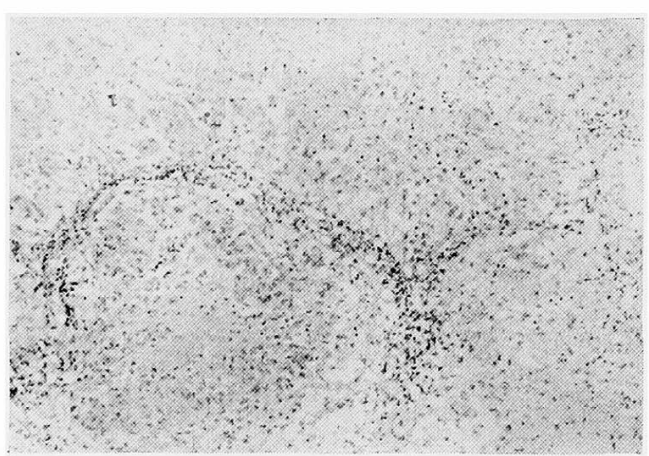

写真 4 サルコイドーシス組織像

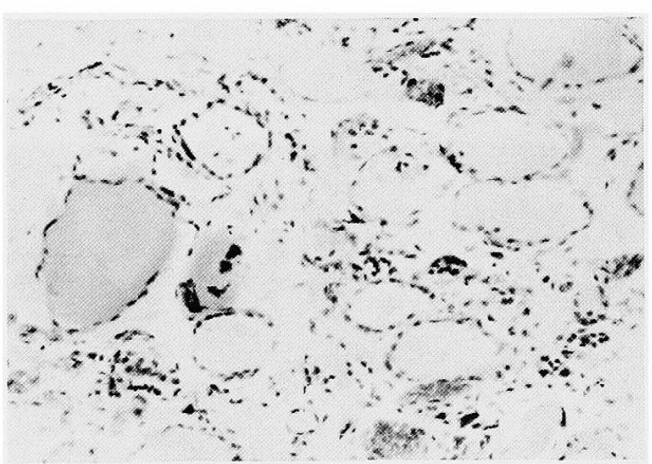

写真 6 胸内甲状腺腫組織像 
久保論文付図（II）

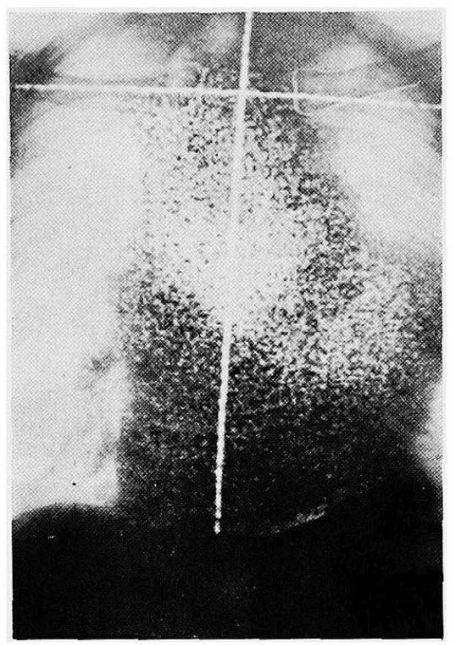

写真 7 胸内甲状腺腫甲状

腺シンチグラム

写真 8 摘出胸内甲状腺腫
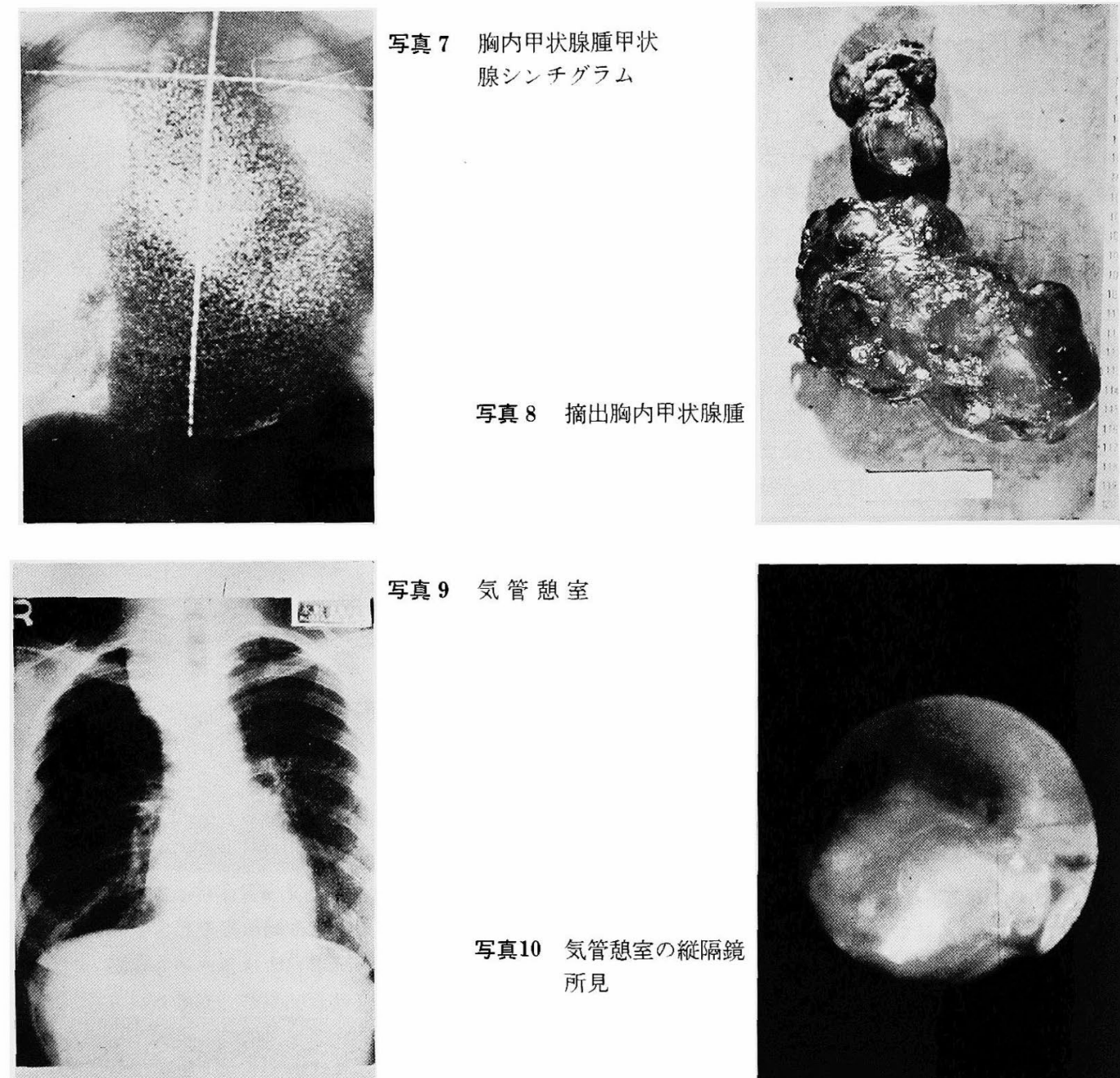

写真 9 気 管憩室

写真10 気管憩室の縦隔鏡 所見

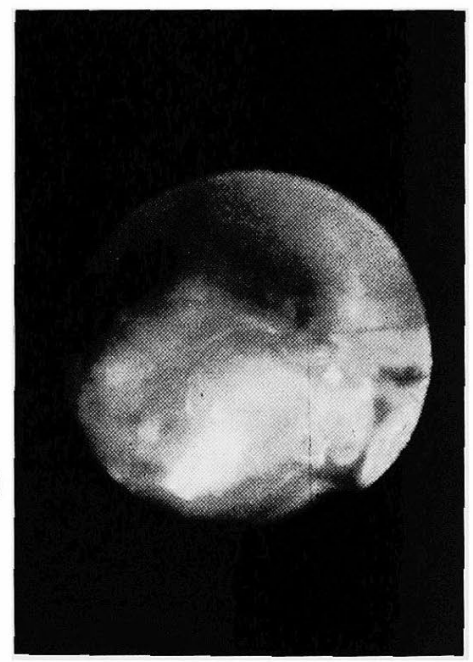

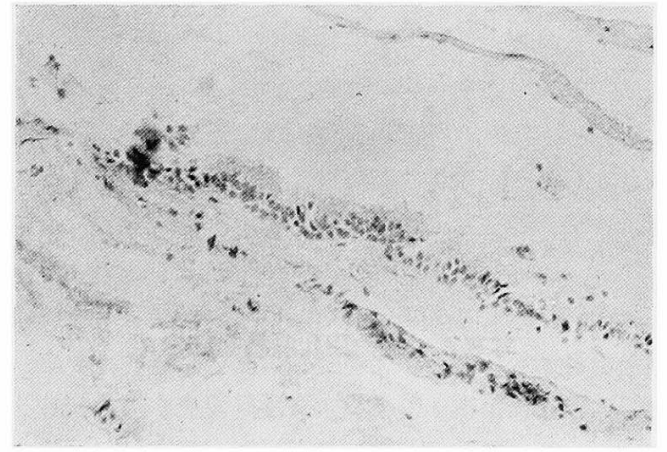

写真11 気管㮩室の組織像

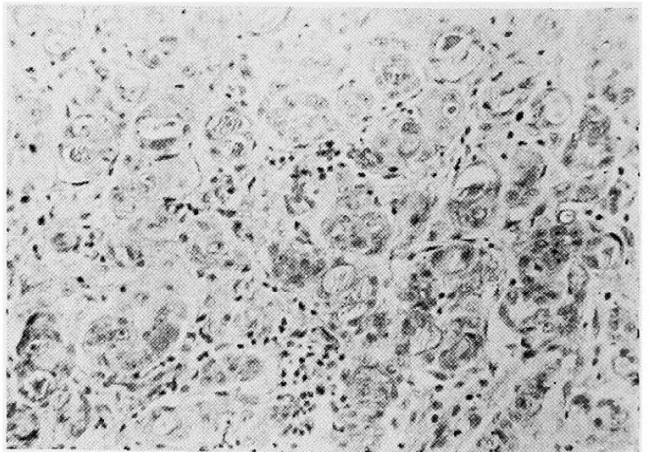

写真12 右気管気管支リンパ節生検より確定診断 された腺癌 
日耳鼻 久保・西田・山崎二肺・縦隔疾患に対する縱隔鏡検查法 (Mediastinoscopy)の実際とその㭘査成績 76一-219

等の循環器異常を有するもの, 高度の甲状腺腫瘤症例が 挙げられる。

本梌查終了後, 咳嫩, 前胸部痛, 背部痛等を訴元る が，㨂管操作および㭘查時の体位に起因するもので，大 体これらの愁訴は $2 \sim 3$ 日で緩解，消失寸る2).

\section{0) 結 語}

(1) 昭和42年より昭和 47 年 2 月までに 27 例の肺・縦隔

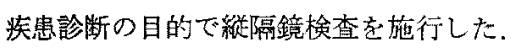

(2) 27 例中, 生検施行例は20例, 非施行例妵 7 例であ つた. 生検例20例について検体からの組織診と, その後 に行われた手術時診断, あるい怯死後剖検所見と一致し た症例は12例であつた。病变部よりの訊験穿刺のみで， 良性の縦隔霍腫之㟝断できた症例が 1 例あつた。

(3) 生検によつて確定診断できた疾患の内訳は, 恶性 腫瑝としては adenccarcinoma 1 例, malignant neopla$\sin 4$ 例であり，良性の腫瘍としては thymoma I例, heterotopic struma 1 例, bronchogenic cyst 1 例, diverticle of trachea 1 例があり, その他炎症性腫熘として の sarcoidosis が 3 例であつた。

（4）検查中, 検查後の遇発症, 合併症は 1 例も経験し なからた。

\section{参考文献}

1) 北村武，他：睡液腺疾患のいろいる(その2) 一 Sarcoidosis について—, 耳喉科, 29；426，1957(昭 32).

2) Carlens, E.: Mediastinoscopy : A methed for Inspection and Tissue Biopsy in the superior Mediasti. num. Dis. chest, $36 ; 4,1959$.

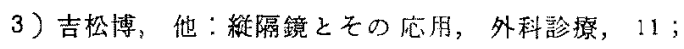
382,1969 (昭44)。

4) 大平一郎, 他: 縱隔腫揚の診断, 日本医事新報, 2069, 8，1963 (昭38).

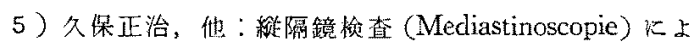

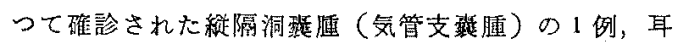
喉科, 40；5，1968(昭43).

6) Koskinen, O., Linden, L.W.F.: Mediastinoscopy in Mediastinal Surgery. Ann of Otolaryng. 23 ; 1, 1964.

7) Tucker, J.A.: Mediastinoscopy with special Reference to the diagnosis of Sarcoid. Ann. of Otolaryng. $29 ; 937,1970$.

8) Carlens, E.: Biopsies in Connection with Bronchoscopy and Mediastinoscopy in Sarcoidosis. A Comparison. Acta Med. Scand. Suppl. 425. p. 237, 1964.

9) Pätiäla, J.: Observation on the significance of Mediastinoscopy in the Diagnosis of Sarcoidosis. Acta Med. Scand. Suppl. 425, p. 239, 1964.

10）久保正治，他：綎隔鏡梌査 (Mediastinoskopie) K ついて, 耳喉料，39；4, 1967 (昭42).

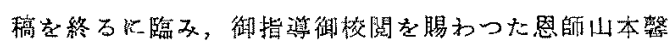
教授に謝意を表します.又, 病理学的に, 御愁第なる御教

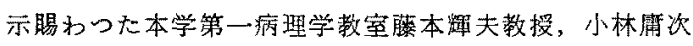
講師蓝び飞第二病理学教室北条慧二勋教授飞梁碀致しま 寸。

更以，外科的摘出磦本以つき，御提供，御教示頂き した本学第二外科学教室白羽弥右衛附教授並び比教室員 各位儿感唧致します，

尚，本検査のために，多数の症例老御紹介頂いた臨 㕅関倸各教室の諸先生方に厚く御礼申し上げをす。

最後に，本检查施行代当り，常に参加，協力媔いた元 当教室藤義孝助手炕感謝の意を䘚します。

（原稿受付 昭和 $47 ， 9 ， 5$ 日) 